\title{
"Workers of the World, Embrace!" Daniel Guérin, the Labour Movement and Homosexuality
}

\section{David Berry}

\author{
I came to socialism via phallism. ${ }^{1}$
}

Only a true libertarian communism, antiauthoritarian and antistatist, would be capable of promoting the definitive and concomitant emancipation both of the homosexual and of the individual exploited or alienated by capitalism. ${ }^{2}$

Daniel Gurin (1904-1988) was a unique and outstanding figure on the French Left for half a century, both as a selfless and committed activist and as a writer. His writings cover a vast range of subjects not to mention several autobiographical volumes and he made significant contributions in many fields, from fascism and the French Revolution to the history of the European and American labour movements; from Marxist and anarchist theory to homosexual liberation; from French colonialism to the Black Panthers; from Paul Gauguin to French nuclear tests in the Pacific. ${ }^{3}$ Similarly, Gurin was involved in various movements and campaigns: always an anti-Stalinist revolutionary, he was also committed to anticolonialism, antiracism, antimilitarism and homosexual liberation. This is a man who counted Franois Mauriac, Simone Weil, C.L.R. James and Richard Wright to name but a few of the famous names which litter his autobiographies among his personal friends; whose earliest literary efforts provoked a letter of congratulation from Colette; who corresponded with Leon Trotsky and met him briefly in 1933; a man who had dinner en tête à tête with Ho Chi Minh. Jean-Paul Sartre judged Gurins reinterpretation of the French Revolution to be one of the only contributions by contemporary Marxists to have enriched historical studies; ${ }^{4}$ the Martinican poet Aim Csaire paid tribute to his work on decolonisation; ${ }^{5}$ Noam Chomsky considered and still considers ${ }^{\sim}$ Gurins writings on anarchism to be of great importance to the development of contemporary socialist thought; ${ }^{6}$ and, closer to the subject of the present paper, the leading gay liberation activist Pierre Hahn believed his own generation of homosexuals owed more to Gurin than to any other. ${ }^{7}$ 
The expression le feu du sang fire in the blood which Gurin chose as the title for his third autobiographical volume, published in 1977, was drawn from Proudhons Philosophie de la misère. Proudhon had used the phrase to describe the entirely physical way in which love, the sole purpose of humanity, was, according to him, understood by the common people. Gurin disagreed with this separation by Proudhon of sexuality from higher forms of love: Personally, I believe that one and the same vital energy or, to use the Melanesian term, one and the same mana, has been the driving force in my political as well as my carnal life. ${ }^{8}$ The purpose of this paper is to attempt to unpack and to understand this claim. What was the relation between Gurins homosexuality or bisexuality and his lifelong commitment to the working-class movement and to revolutionary socialism? How did he perceive and theorise if at all the intersections between the different kinds of oppression based on class, race, sexuality and gender which he spent his life fighting?

The paper can thus be divided into two basic parts which will engage with these two different aspects of the question, as represented in the quotations from Gurin included above as epigraphs: firstly a biographical account of $\mathrm{Gu}$ rins discovery of the working class and of the links between this and his homosexuality; and secondly a discussion of his attempts to generalise from these experiences and to theorise the question in order to inform his political choices. The biographical approach enables us to understand the depth of Gu rins own feelings about the issue of sexuality a depth of feeling which is not at all evident in writings about Gurin outside of gay circles. Jean Maitrons entry on him in the Dictionnaire biographique du mouvement ouvrier, for instance, does not even mention homosexuality; and the obituary by a close associate of Gurins, Daniel Guerrier, ironically entitled Un militant sans frontires, An activist without borders, mentions it in one short sentence. ${ }^{9}$ The biographical approach is also important because although Gurin is clearly an exceptional figure by many standards, his experiences as a homosexual working as an activist within a predominantly homophobic labour movement were without doubt shared by many others, but very few such activists have written or spoken out about the suffering they endured and the dilemmas with which they were faced in private as a result. The theoretical approach is important if we are to understand Gurins own political evolution, notably with regard to his long-term attempts to elaborate a form of revolutionary socialism which built on the traditional priorities of Marxist-dominated European labour movements, whilst embracing the libertarian concern with revolution in everyday life and in interpersonal relationships. His concern to advocate sexual derepression as part and parcel of the road to socialism place him in a relatively select band of twentieth century thinkers and activists (alongside such as Wilhelm Reich); and his emphasis to use present-day jargon on the dynamic interplay (or dialectic, as Gurin would doubtless have put it) between 
claims for redistribution and recognition struggles meant that Gurin was in certain important respects years ahead of his time. ${ }^{10}$

\section{A road to Damascus? Guérin's homosexuality and his 'discovery' of the working class}

Looking back on the period when he first became involved in the labour movement in 1930, Gurin wrote:

I found myself to be at once a homosexual and a revolutionary, without being able to distinguish clearly to what extent this was due to the intellect (reading and reflection) and to what extent it was due to feeling (physical attraction to the working class, revolt, rejection of my bourgeois background....). ${ }^{11}$

Elsewhere, on several occasions, he claimed more baldly that it was through his sexual relationships and his friendships with young working-class men that he came to socialism, and that visceral empathy weighed much more in the balance than any intellectual or theoretical considerations:

It was through this contact that I discovered the living conditions, the way of life, the frame of mind of the working class. It was there, in bed with them, that I discovered the working class, far more than through Marxist tracts. ${ }^{12}$

There were, in fact, several factors determining the unusual routes by which this son of the bourgeoisie sought to merge with the people in order, ultimately, to put himself at the service of the Revolution. ${ }^{13}$ First, Gurin was clearly influenced by the relative progressiveness of his family background, however objectively bourgeois and reactionary it may have been: liberal, humanist, Dreyfusard and antiracist, with strong antimilitarist and even Tolstoyan tendencies. By the time he was a student at Sciences Po (the prestigious School of Political Science in Paris, which he attended from 1921), Gurin identified with the Marxist extreme left in the context of the increasingly polarised debates of the period between extreme right and extreme left: Maurras versus Marx, as he put it. ${ }^{14}$

Second, the physical attraction of the working class. This coincided with Gurins discovery of the working class in 1925, when, having completed his studies and his military service, he was sent to serve his apprenticeship working for the family firm, Hachette. He was given a menial clerical job in a 
building in the La Chapelle quarter $\left(10^{\text {th }}\right.$ arrondissement), behind the Gare du Nord, adjacent to a street used by prostitutes and in the heart of an authentically proletarian quarter. ${ }^{15}$ This and the metro journey there and back were an eye-opener for Gurin, whose life until then had been restricted to a virtually sealed social environment, shared between the family homes in the most bourgeois quarters of central Paris, the prestigious Louis-le-Grand Lyce and Sciences Po, bastion of liberal capitalism with an entirely bourgeois student body. Even during his military service he had of course been a trainee officer. Gurin had been kept utterly ignorant of the greater part of Paris and particularly of the more proletarian areas. I was restarting my life from scratch, Gurin noted in his Autobiographie de jeunesse. ${ }^{16}$ This was true both in terms of his sexuality and of his social horizons, for he now discovered not only a whole series of willing sexual partners among the working class, he also came to know their environment: The effect which these young workers had on me was not simply that I desired them, but that they opened to me the unlimited perspective of the class struggle. ${ }^{17}$ In a 1979 interview, he talked of the symbiosis between him and his many working-class sexual partners:

That is how I gradually came to have a greater and greater understanding of their way of life and a profound feeling of human solidarity in the face of exploitation and poverty. It wasnt a case of one, two or three experiences, such as any young bourgeois might have with a young girl; I had 15, 20 or $30 . .^{18}$

In another interview the same year, he spoke of his feelings for young working-class men as representing a sort of erotic pantheism, a generic feeling, suggesting in a manner reminiscent of Jean Genets (in)famous remarks about his support for Algerian nationalism that this was how being attracted to young men brought him to adhere to revolutionary socialism: The fact of so loving those young workers led me, logically, to make mine the struggle of the whole working class, the struggle of all the exploited and oppressed. ${ }^{19}$

Gurin also remarked that: There was also in my liking for young working-class men an element of rebellion against the established order, against my family. ${ }^{20}$ Of an occasion when he secretly brought back one of his workingclass lovers to the family apartment in the Boulevard Saint Michel, he wrote: I did not invite [Marcel] back to our apartment purely because of my feelings for him: there was also a certain appetite for social transgression. I was throwing down a challenge to my family, ${ }^{21}$

In 1927, Gurin accepted the offer of taking over the management of the Syrian branch of Hachette. The journey to Beirut (capital of what was then the 
French protectorate of Syria) and a subsequent one to French Indo-China (Vietnam) were to prove to be life-changing experiences:

Although I did not realise it at the time, I was abandoning not only the family home, I was also leaving behind me other shores: bourgeois society and Europe. I was heading for a series of unknown lands: the Orient, Islam, Asia, decolonisation, and, beyond, socialism.

He would finally return to France in 1930 determined to cut all family ties and to devote himself to the cause of the international working class. He found somewhere to live in Belleville, a traditional working-class quarter of Paris: I liked it there. I moved into the heart of the class struggle. ${ }^{22}$ Looking back on this new departure, he would write:

It was not in books, it was first of all within me, through years of sexual frustration, and it was in the contact with the oppressed that I had learned to hate the established order. The sexual quest had delivered me from social segregation. Beyond the beautiful torsoes hardened by physical labour ..., what I had been looking for was camaraderie. That was what I hoped to find a hundredfold in socialism. ${ }^{23}$

He came to see his social commitment as a form of sublimation of his own sexuality in his new aim in life: The liberation of all, which would, at the same time, be mine. ${ }^{24}$

By the time of the 1936 strikewave (precipitated by the election of the Popular Front government), Gurin was working as a local organiser for the CGT in Les Lilas in the so-called red belt on the outskirts of Paris. This period represented a determining experience for Gurin in political terms. His involvement in mass meetings and in helping to organise strikes and occupations was also one of the major emotional experiences of his life:

I often experienced more homosexual satisfaction through being the object of such fraternal attention than if one of them had bestowed his favours upon me. I have never felt so sexually alive as when at the front of a vast meeting hall full of young proletarians. It was as if I was bathed in a sort of homosexual element. In fact, I have never lived my homosexuality so totally as during the great historic moments such as 1936 and 1968; it was my own way of living it. ${ }^{25}$ 
But it was not just contact with the working class which turned Gurin into a revolutionary, it was his experience as a homosexual, the humiliations and never to be forgotten outrages ${ }^{26}$ which he had to endure because of his sexuality which turned him against the existing values of bourgeois society: The stupidity of homophobes knows no bounds. It creates revolt. And revolt is the breeding ground of Revolution ${ }^{27}$

It was also his direct, personal knowledge of the bourgeoisie which turned Gurin away from his own class. In particular, he was disgusted with the immense hypocrisy of his class, with the disparity between the morals it preached and the private realities of its sexual behaviour. Gurin found a striking contrast with the behaviour of the working class a recurring theme in his autobiographies and interviews:

As far as young workers were concerned at least those I met, one must never generalise $\mathcal{I}$ was always struck by the lack of hypocrisy and affectation, the ease, the cheerful and uninhibited way in which they enjoyed both heterosexuality and homosexuality. ... It was possible for two men to dance together to the sound of the accordion at the balls in the rue de Lappe. It was perfectly acceptable. People werent shocked. ${ }^{28}$

Gurin on several occasions insisted on the fact that in the 1920s young working-class men (particularly soldiers and sailors) did not suffer the homophobic prejudices which were to become commonplace after the Liberation due to the embourgeoisement and increasing social conformism of the proletariat, according to Gurin: There was a kind of facility in relations between men from very different social backgrounds which I have not come across since. ${ }^{29}$ Whether this represents a kind of idealisation of the working class on Gurins part is difficult to say given the present state of research. As Florence Tamagne comments, It would suggest a high degree of tolerance of homosexuality on the part of the working class, something which is difficult to prove, as firsthand accounts by homosexuals from modest backgrounds are very rare. On the other hand, she concedes, there is plenty of evidence in the form of published writings which do record the relative indifference of workers towards homosexuality. ${ }^{30}$

\section{Living two lives: homophobia in the socialist and labour movements}

For many years, Gurin lived what he referred to as a cruel dichotomy. ${ }^{31}$ With friends and comrades to whom he felt quite close, and in whom he was able to confide as far as other things were concerned, Gurin nevertheless had 
to bite his tongue and refrain from raising anything to do with sexuality, and it was certainly inconceivable that he should ever attempt to defend a non-orthodox version of love, ${ }^{32}$ even from a detached point of view. Speaking in an interview of his life as a trade union and Socialist Party activist in the 1930s, he said:

There were within me two men and two lives. In one life, I was exclusively an activist and in the other I was, depending on the period, more or less tormented by my homosexuality, but there was never any link between my two selves. I certainly refrained from broaching the subject in front of any labour activists. ... If other comrades were living with similar problems, it was only much later that I found out. There really was no interference between my two lives. ${ }^{33}$

The revolutionary syndicalist Pierre Monatte, with whom Gurin worked when he first joined the labour movement in 1930, was as narrow-minded in his personal life as he had been daring in his past life as an activist, and he and the group of militants around him, although they allowed Gurin to work with them, never entirely disarmed because of their profound suspicion both of supposedly sympathetic sons of the bourgeoisie and of intellectuals. So Gurin was already doubly damned thanks to the workerist and anti-intellectual traditions of French syndicalism. Indeed, Gurin felt their distrust to be quite reasonable, despite the fact that it made his own position rather difficult.

Also, as Gurin himself perceived it, he was forever on the margins ideologically speaking, his impenitent leftism meaning that whichever group he was a member of he always seemed to gravitate towards its most revolutionary wing: he became critical of Monatte and others when their obsessive anti-stalinism pushed them into the arms of Lon Jouhaux; he gravitated towards Marceau Piverts Revolutionary Left within the reformist Socialist Party, and towards the Trostskyists and revolutionary defeatists within the PSOP (the Workers and Peasants Socialist Party). So Gurin was already not short of enemies. To add yet another factor of marginalisation (his homosexuality) to this already significant handicap would have been just too much. ${ }^{34} \mathrm{He}$ lived in constant fear of any of his new comrades in the syndicalist and socialist movements stumbling across some of his youthful literary attempts at least one of which, his 1929 novel La Vie selon la chair, dealt more or less explicitly with homosexuality.

The two sins his homosexuality and his class background were of course linked, in that it was a common misconception that homosexuality was a bourgeois vice, similarly to the way in which it would in later years be seen as being in some way intrinsically linked to fascism. This is doubtless why 
Gurin put some effort into disseminating research which demonstrated that homosexuality was just as common among the working class as any other class, but which also highlighted the different experiences of working-class and bourgeois homosexuals "both in terms of the conditions that working-class homosexuals were forced to endure in their attempts to meet other homosexuals (public urinals as opposed to private clubs and salons) and in terms of harassment by the authorities (as contrasted with the relative tolerance of homosexuality in bourgeois and artistic circles). ${ }^{35}$

Gurin is emphatic about the abject misery caused for him personally and for all those in a similar position by the constant fear of being discovered and unmasked by a comrade whom one respected and admired, of losing their respect and even of becoming scorned and loathed. One was forced, at all costs, to remain silent, to dissemble, to lie if need be, in order to preserve a revolutionary respectability whose price could be measured only in terms of the abjection one risked falling into if one dropped the mask. ${ }^{36}$ He would have to wait until the 1960 s, and 1968 in particular, to be delivered from this burdensome daily secrecy. ${ }^{37}$ At meetings of Arcadie (a moderate and predominantly middle-class, reform-oriented homophile association), he would come across comrades from his early days in the labour movement who had also felt compelled to hide their homosexuality. ${ }^{38}$ Although it has often been tempting for the more workerist Marxists and others to mock the revolutionspiel of 1968, it certainly represented a very real liberation for some.

\section{"The disalienation of each individual." For a dialectic of homosexuality and revolution}

There are certain elements in Gurins ideological position which remained constant throughout his political life: notably an attachment to historical materialism, marked workerist tendencies and a belief in the centrality of organised labour. ${ }^{39}$ Nevertheless, partly as a result of his own experience of the suffering caused by homophobia, partly as a result of a developing critique of what he saw as the Jacobin traits within Marxism and especially bolshevism, from the 1950s Gurin came to be more influenced by an anarchistic concern with the alienation of the individual. He was still active on the revolutionary antiStalinist left; he was heavily involved in anti-colonial campaigns and worked to support the black liberation movement in the United States (he wrote an introduction for his daughter Annes translation of the autobiography of Malcolm X, for example). ${ }^{40}$ But in the 1950 s, he began to write more and more about sexuality, and he finally came out, no longer able to bear the schizophrenic split between the two parts of his life, in 1965, with the publication of his first autobiography, Un jeune homme excentrique. ${ }^{41}$ By the time he pro- 
duced Homosexualité et Révolution in 1983, just five years before his death, the definition he provided of Revolution stressed that it should be seen not only as the rising up and self-emancipation of the oppressed masses, but also as the disalienation of each individual. Hence the need to establish a dialectical relationship between the words homosexuality and Revolution. ${ }^{42}$ How was this dialectic to be established, and what critique of the existing revolutionary movement (and of the homosexual movement) did it imply?

\section{The left and homosexuality: a critique}

Not so many years ago, to declare oneself a revolutionary and to confess to being homosexual were incompatible, Gurin wrote in $1975 .{ }^{43}$ All in all, Gurin did not have a positive opinion of the European labour movements record on homosexuality: the record is very poor, beginning with Engels, whose study of the origins of the family discussed the possible causes of homosexuality before dismissing it as a disgusting vice. ${ }^{44}$

Gurin pointed out that in the beginning, at least, revolutionary Russia adopted an exemplary attitude to sexual and homosexual liberation, but he was scathing about the USSR under Stalin and the post-1945 socialist states in Eastern Europe and Cuba. One of the reasons why the post-war generations of gays were distrustful of revolutionary politics, according to Gurin, was the abject failure in this regard of actually existing socialism:

The intransigence of the so-called communist regimes in this regard takes much more shocking forms than that of the capitalist countries. It is paradoxical and scandalous that the zealots of so-called scientific socialism should display such crass ignorance of scientific facts. It is tragic that a morbid puritanism be allowed to so disfigure the natural and polymorphous eroticism of an entire generation. ${ }^{45}$

But why were homosexuals persecuted under Stalinism?

The reason is that the homosexual, whether he knows or wishes it or not, is potentially asocial, an outsider, and therefore a virtual subversive. And as these totalitarian regimes have consolidated themselves by resuscitating traditional family values, he who loves boys is considered a danger to society. ${ }^{46}$

As for the French left, the PCF (Parti communiste franais, French Communist Party) was hysterically intransigent as far as moral behaviour 
was concerned"47; the Trotskyist Pierre Lambert's OCI (Organisation communiste internationaliste) was "completely hysterical with regard to homosexuality"; Lutte ouvrière was theoretically opposed to homosexuality; as was the Ligue communiste, despite their belatedly paying lip service to gay lib. ${ }^{48}$ Together, Guérin argued, such groups bore a great deal of responsibility for fostering homophobic attitudes among the working class as late as the 1970s. Their attitude was "the most blinkered, the most reactionary, the most antiscientific". 49

In an appendix of his 1955 study of Alfred Kinsey, Guérin took the opportunity to argue for a change of attitude:

Revolutionaries have proven themselves to be no more tolerant than the bourgeois with regard to homosexuality. They have, it is true, an excuse: they distrust the homosexuals in their ranks because the latter are reputed to be vulnerable to blackmail and to pressure from the police, and are therefore 'dangerous' for the movement which, in the eyes of such activists, is more important than respect for the human individual. But they do not realise that their intolerance itself contributes to perpetuating the state of affairs which is at the root of their concern: by virtue of the fact that they also cast their stone at homosexuals, they are helping to consolidate the very taboo which makes homosexuals easy prey for the blackmailers and for the police. The vicious circle will only be broken when progressive workers adopt both a more scientific and a more humane attitude towards homosexuality. ${ }^{50}$

It is not surprising that Guérin should have been attacked by the Catholic Church, but he also came under fire from the Left, and in particular the PCF. The Trotskyist Michel Raptis (Pablo) also apparently complained in his review of the Kinsey book of an over-concentration on homosexuality. ${ }^{51}$ Guérin was not surprised. As he wrote in a letter to the 'anarchisant' sexologist René Guyon, whose work he much admired: "The harshest [criticisms] came from Marxists, who tend seriously to underestimate the form of oppression which is antisexual terrorism." 52

Eventually, Guérin had had enough, and he finally came out with the publication of Un jeune homme excentrique, in 1965:

These guardians of society's 'morals' have inadvertently done me a favour: they have made me face up to them without false shame and come to terms with myself more fully. Gone are the days of the fruitless and absurd split between 
two halves of myself: one half which was seen and another which had to remain hidden. Totality has been re-established. ${ }^{53}$

However, his attempt to explain the relationship between his discovery of the working class, his sexuality and his socialism, shocked and was misunderstood by many on the left:

My background had enclosed me within the opaque barriers of social segregation; homosexuality, by making me intimately familiar with young workers, by enabling me to discover and share their life of exploitation, led me to join the class enslaved by the class I was leaving behind. This simple explanation, perhaps too simple, was not to the liking of everybody. ${ }^{54}$

He was accused of dishonouring not only himself, but the whole of the left, by suggesting that one had to be a 'pédé' (queer or fag) to be a socialist: "Thanks to me, people might have suspected all 'leftists' of siding with the labour movement for the pleasure of 'a bit of rough'!' Jean Daniel, editor of Le Nouvel observateur, allegedly organised a boycott, actively discouraging colleagues from reviewing the book. ${ }^{55}$ Guérin found few defenders, and even someone such as the left-wing, gay novelist Jean-Louis Bory remained silent. ${ }^{56}$ Guérin reported that one reader and admirer of his celebrated study of anarchism was profoundly disappointed that the author of such a 'serious' work could also have penned Un jeune homme excentrique. ${ }^{57}$ Indeed, Guérin's readers seem to have always fallen into one of two kinds: "I have two publics: some people buy all my books on political and social questions, whilst others are only interested in my literary and homosexual writings. $" 58$

Even the organisations of which Guérin was actually a member were not beyond criticism. In 1958 , before he had come out as a homosexual, but at a time when he was concerning himself more and more in his writings with questions of sexuality, material submitted both to France-Observateur and to Perspectives socialistes - the latter being the organ of the Union de la gauche socialiste, of which he was a member - was censored without his being told:

Thus, in two papers to which I contribute and whose political positions are close to my own, it is impossible for me to raise issues of sexuality without being gagged. But the battle for the emancipation of man on all levels continues, and we shall, in the end, triumph. ${ }^{59}$ 
He commented resignedly in an interview for Masques that the OCL (Organisation Communiste Libertaire), of which he had been a member in the early 1970 s, had simply never mentioned sexuality: "It's not hostility, but they forgive me some deviations because I've written books about anarchism." Things would only change for Guérin with the appearance of the UTCL (Union des Travailleurs Communistes Libertaires), of which Guérin would remain a member from its creation in 1978 until his death ten years later. ${ }^{60}$

\section{For (homo)sexual liberation: Fourier, Stirner, Reich, Kinsey}

For Guérin, the revolutionary movement needed to concern itself not just with homosexuality, but with sexuality in general, the libido: "The problem which confronts us, therefore, is knowing whether the free exercise of the sexual instinct is compatible with the contingencies and demands of the revolutionary struggle." 61 Some, like Proudhon, Robespierre and Lenin saw 'virtue' as the basis of revolutionary activism and emphasised the need for continence in the struggle against the existing order. Others, notably in 1968, argued on the contrary that "orgasm goes along with the revolutionary's furia." 62 Clearly, Guérin argues, excess is not conducive to effective revolutionary struggle, it is a question of balance, and this is as true of homosexuality as of any other form of sexuality: "Whatever some class-struggle prudes may say, homosexuality ... has never diminished the revolutionary's commitment and combativity, on condition, of course, that excess and promiscuity are avoided." 63

The groundbreaking work of Alfred Kinsey (published in French translation in 1948 and 1954) was without doubt the most important influence on Guérin in his attempts from the 1950s to formulate a critique of homophobia and put forward an argument for a more general sexual liberation, and doubtless played an important part in giving Guérin the courage to write about homosexuality. Serious studies of sexuality were few and far between in France between the 1930s and the 1950s, and the PCF's position on 'sexology' and psychoanalysis was as repressive as that of the Catholic Church. Guérin's study of Kinsey, published by Julliard in 1955, was thus at once groundbreaking and controversial. ${ }^{64}$ It represented for Guérin a major step forward in that he was able to use the opportunity to present a public defence of homosexuality. ${ }^{65}$ Guérin argued that if, before Kinsey, it might have been possible for socialists and communists, eager for the overthrow of capitalist exploitation, to join with Lenin in considering the sexual question of secondary importance, as an adjunct of the central struggle, such an attitude was no longer tenable after the publication of the Kinsey Report. The Report "encourages us to pursue simultaneously both the social revolution and the sexual revolution, until human beings are liberated completely from the two crushing burdens of capitalism 
and puritanism." 66

There were other influences on Guérin's thinking about sexual liberation, notably among the anarchists. In his youth, Guérin read Eugène Armand's individualist anarchist organ L'en dehors, which used to campaign for complete sexual freedom, and for which homosexuality was regarded as an entirely valid form of 'free love'. ${ }^{67}$ Much later, Guérin discovered the German individualist anarchist, Max Stirner. If some anarchist-communists have been a little puzzled by Guérin's interest in Stirner - generally anathema to the non-individualist wing of the movement - the answer lies in what Guérin perceived to be Stirner's latent homosexuality, his concern with sexual liberation and his determination to attack bourgeois prejudice and puritanism: "Stirner was a precursor of May $68 " .68$

Guérin was also a great admirer of the 'utopian' socialist Charles Fourier, at least in so far as his arguments in favour of sexual liberation and tolerance were concerned: "I was as one with the genial Fourier when he ennobled and sanctified all sexual acts, including those he termed 'ambiguous'."69 Fourier himself was the victim of censorship on the part of his own disciples, and his Nouveau monde amoureux, written in 1816-18 but suppressed by the Phalansterians (Fourier's followers) on the grounds that it was immoral, was only published in 1967. Guérin was delighted at its appearance:

The great utopian wants to see no form of attraction repressed for, an ancestor of Freud, he is too well aware of the psychological damage done by the constriction of the instincts and how unhappy we are when we are struggling against ourselves. Even more serious than the individual suffering caused by the repression of the passions are the effects on society. If they are held in check, they immediately reappear in a more harmful form which Fourier called 'recurrent', and it is then and only then that they create disorder. ${ }^{70}$

Fourier thus lends support to Guérin's critique of "the curse which Proudhon was to put on Eros on the pretext of protecting industry ... in Harmony, the more each individual's tastes are satisfied, the better the community will be served. ${ }^{71}$

In 1975, Guérin published an anthology of Fourier's texts on sexual liberation, Vers la liberté en amour, with a lengthy preface which included a detailed analysis of Fourier's scattered and sketchy references to homosexuality. ${ }^{72}$ Guérin contributed to the new-found popularity of Fourier among the generation of 68 , and the same can be said to some extent of Wilhelm Reich, with whom Guérin shared a taste for syntheses and the experience of being 


\section{Berry}

condemned as a heretic by the defenders of orthodoxy.

What Guérin admired in Reich was his attack on the socially conservative aspects of Freud's theories - notably, again, the notion that suppression of the sexual instinct was necessary for civilisation - and Reich's emphasis on 'antisexual' attitudes as being historically determined:

The repression of sexuality has social and economic origins, not biological ones. Sexual repressiveness appeared with the beginnings of class society and the institution of private property and patriarchy. ... In modern times, such repression remains indispensable in order to safeguard the two essential institutions of society: monogamous marriage and the family. It constitutes one of the means of economic enslavement. The sexual revolution is only possible through social revolution. ${ }^{73}$

Although Reich had, in his time, been attacked by both Marxists and psychoanalysts, Guérin would insist in a debate in 1969 that it was precisely this uncomfortable position astride both schools of thought which was now his strong point:

A Marxism which sought to emancipate man without including sexuality in its analysis and liberating man on the sexual level as well would be disfiguring itself, it would be incomplete. A purely biological or purely clinical sexology which paid no attention to the social context and to dialectical materialist analysis would produce only half-truths. ${ }^{74}$

Guérin's only serious criticism of Reich was his relatively conservative position on homosexuality, namely that homosexuality was an aberration caused by restrictions imposed on 'normal' heterosexual relations. Guérin seems to have believed that Reich's hostility to homosexuality was caused by the fact that he was himself a repressed homosexual. ${ }^{75}$ Guérin preferred the more libertarian implications of Kinsey's findings - although Kinsey himself was no apologist for homosexuality and was criticised by Guérin for not taking sufficient account of the socio-historical aspect of the question.

\section{Women and patriarchy}

Guérin has been criticised, notably by Peter Sedgwick, for neglecting the question of women's oppression. ${ }^{76}$ It is certainly true that women are strikingly absent from Guérin's autobiographical writings, and that his representations of 
the working class and of the world of work tend to be male-centred. Nor have I as yet found any evidence in Guérin's archives of any links with feminists, apart from some brief correspondence with the American Trotskyist and feminist anthropologist, Evelyn Reed. ${ }^{77}$

Nevertheless, Sedgwick concedes, "as a historian of the French Revolution Guérin revives the militant memory of the Sociéte des femmes républicaines révolutionnaires, whose liquidation by the Robespierrists is signalled as a clear indicator of the reaction endemic in a bourgeois leadership." 78 He was also, as we have seen, a great populariser of Fourier, for whom, famously, the progress made by any society could be measured in terms of the degree of emancipation of the women in that society.

Several of Guérin's later writings on sexuality and homosexuality also raise the linked questions of gender identity and patriarchy. In 1958, Guérin argued in a discussion of the repression of homosexuality in France that the question had to be seen as just part of a much broader set of issues:

I insist on maintaining that the homosexual cannot and must not be seen as a separate problem, and that the liberation of the homosexual must not be seen as the egoistic demand of a minority. Homosexuality is just a particular form, a variation, of sexuality and must be considered in the broadest context. ... The prejudice with which this mode of behaviour is besmirched derives, in large part, from patriarchal society's depreciation of femininity, considered as 'inferior'. Seen in this way, the cause of the homosexual is the cause of woman. ${ }^{79}$

So, argued Guérin, it was not only article 331 of the Penal Code (outlawing homosexual relations between a major and a minor of less than 21) which must be attacked, but also all those concerning patriarchy: the authority of the 'head of the family', divorce, contraception, artificial insemination, abortion, prostitution and so on. The genealogy of the existing legal situation was clear: De Gaulle in February 1945 had perpetuated Pétain's law of 1942, which itself must be seen in the context of the reactionary Code de la Famille introduced by decree in July 1939 and which attacked all sexual activity outside of the family "where, according to our monogamous civilisation, sexual life must be enclosed." $" 80$

For Guérin, it was bourgeois society which was responsible for "detestable division of the sexes", for pushing to an excessive extent the differentiation between the sexes: "It has been happy to reduce woman to the level of a doll, a 'bimbo', a sexual object, a pin-up girl, whilst simultaneously accentuating the opposite traits in the male - macho, conceited, boorish and tyrannical." 
There were thus clear connections between patriarchal society's oppression of women and its oppression of homosexual men:

Patriarchal society, resting on the dual authority of the man over the woman and of the father over the children, accords primacy to the attributes and modes of behaviour associated with virility. Homosexuality is persecuted to the extent that it undermines this construction. The disdain of which woman is the object in patriarchal societies is not without correlation with the shame attached to the homosexual act. It is doubtless his femininity, his betrayal of virility, supposedly superior, for which the invert is not forgiven. ${ }^{82}$

Pursuing a similar argument in Eux et Lui, he concluded: "woman had become my companion in adversity, my ally." 83

\section{Androgyny and bisexualism}

The idea of some kind of original, pre-lapsarian androgyny was one which interested and appealed to Guérin. He was fascinated with the image in classical myth of an original being cut into two halves, and commented in an interview given at the age of 74 that "I have still not been able to come to terms with the idea that there are two separate sexes. For me, it is quite incomprehensible and it seems to me that this is the result of a kind of amputation carried out on this original being." 84

This 'amputation' was something he felt in his own emotional life. In the 1982 foreword for his 1929 novel La Vie selon la chair, Guérin spoke of the lead female character Hélène as representing "my own feminine side". Of Hélène and her rival Hubert - rival for the affections of another man - he wrote "I was at the same time Hélène and Hubert". In the self-questioning, self-critical text Eux et lui, he wrote - in the third person - of the deep contradictions which he discerned in many aspects of his personality:

His eroticism was no less contradictory .... He was annoyed with girls for not having a phallus and with boys for having no breasts. He resented girls for stealing boys from him and boys for stealing girls from him. The division of the sexes caused him a malaise which was enough to destroy his joie de vivre and to alienate him from the world. He tried to persuade himself that this division was less definitive in nature than in civilisation, that custom and fashion exaggerated it, that human emancipation was tending to reduce it, that man 
is in woman and woman in man. He even tried to savour the contrast and the diversity which are its products and which ought to have consoled him for the strange schism. But, the time not yet having come for a certain reunification of the sexes, he was tired of always hearing people talk of 'man' when in fact he very clearly had before his eyes two different species, and his melancholy at not being able to choose between the two poles was inconsolable. He had a foot in both camps. He dreamed of being the ram with the ewe and of being the ewe with the ram. Being both ram and ewe, he was neither ram nor ewe. ${ }^{85}$

Guérin was not only convinced that homophobes were in many cases repressed homosexuals, ${ }^{86}$ he talked of "bisexual universality" 87 and claimed that bisexuality was the natural human state: "It certainly seems that ... heterosexuals, conditioned by society, are bisexuals without realising it or who censor themselves, or who, quite simply, only allow the heterosexual aspect of their lovemaking to show." 88

He believed there was "a tendency towards unification, towards a reconciliation of the sexes, through sensitivity, creativity, intelligence. I think the society of the future will be a bisexual society." 89 On more than one occasion, he expressed satisfaction at recent cultural trends which seemed to some extent to represent a reversal of the process of differentiation of the sexes, and he was positively delighted that, as he put it, it was sometimes difficult to tell the difference between young men and women in the street. But he was also aware that such trends were limited: "We are still a long way from a symbiosis, something which, it would seem, only the Social Revolution, thanks to its equalizing and reconciling aspect, would be able to achieve. $" 90$

\section{Homophobia as racism}

As well as seeing parallels between the situation of women and homosexuals, Guérin argued that homophobia was akin to racism, and that in terms of the situation in which they found themselves in their everyday life, the suffering of homosexuals could be compared to that of blacks or Jews:

One only has to read the admirable analysis offered by Frantz Fanon, in his Black Skin, White Masks, of the permanent dread of the Black in the face of the White's racial prejudice to understand to what extent the fate of the homosexual resembles that of the man of colour. The writer Richard Wright, as heterosexual as they come, sympathised equally 
with the comparable condition of the Black, the Jew and the 'queer'. ${ }^{91}$

Guérin's homosexual encounters in the colonies in the late 1920s undoubtedly played a rôle here, $a \grave{~} l a$ Genet. ${ }^{92}$

Interestingly, Guérin chose to include in a short collection of speeches, published in 1968, a letter from a member of the audience at one of the meetings concerned who had responded to comments Guérin had made about 'psychological minorities'. The writer attacked what they saw as the complacency and hypocrisy of most left-wingers who think of themselves as anti-racist, but who are full of "disdain for alcoholics, prostitutes, homosexuals, etc ... who therefore fulfil for these 'anti-racists' the rôle of substitute Jew, of replacement nigger." For, the letter argued, "if racism is disdain for a community different from us ..., racism in the full meaning of the word is not only or necessarily directed at people of another colour." $" 93$

\section{For a total revolution}

In 1969, Guérin was interviewed by François Bott for Le Monde. Guérin's Essai sur la révolution sexuelle après Reich et Kinsey and his Pour un marxisme libertaire had both just appeared. ${ }^{94}$ Asked if this simultaneity was a coincidence, he replied emphatically "Non":

The subjects dealt with make a whole. The libertarian critique of the bourgeois regime is not possible without a critique of bourgeois mores. The revolution cannot be simply political. It must be, at the same time, both cultural and sexual and thus transform every aspect of life and of society. ... The revolt of the spring of 68 rejected all the faces of subjugation..$^{95}$

Going on to speak of his proposed synthesis of anarchism and Marxism, he clarified the social, political and organisational aspect of his vision. Despite Guérin's move towards the anarchist movement (due partly to the sexual question, but also in large part to the intransigent opposition to the Algerian war demonstrated by militants of the Fédération Communiste Libertaire ${ }^{96}$ ) and his growing interest in the notion of spontaneity, ${ }^{97}$ Guérin maintained a belief in the rôle of "conscious, activist minorities" ('minorités agissantes'). But these must be minorities "in a symbiotic relationship with the working class, and with their roots in the workplace." 98 He wanted to see such groups fostered by the trade union movement and emerging from it to fight for the socialisation of the economy and, ultimately, "to ensure self-management by workers' councils 
within a federalist structure." This emphasis on the role of organised labour was one of the main reasons for his decision to join the UTCL rather than other more 'spontaneist' groups of the time which were hostile to the trade unions.

Given Guérin's belief that attitudes towards homosexuality were intrinsically linked with the role of the authoritarian family and of patriarchal gender roles, "cornerstone of the social order", he was convinced that it was unrealistic to expect to be able to eradicate homophobia without attacking the rest. As with racism, reformist means would not suffice in sweeping away the "homophobic prejudice, in all its hideousness":

[The bourgeoisie] cannot deprive itself of the help provided for it by, on the one hand, the glorification of marriage and the cult of procreation, and on the other, the support given it by the Churches, determined adversaries of free love and of homosexuality. ... The bourgeoisie as a whole will never entirely lift its ban on dissident sexualities. The whole edifice will have to be swept away in order to achieve the complete liberation of man in general (a generic term which includes both sexes), and of the homosexual in particular. ${ }^{99}$

Having said that, Guérin was not dismissive of partial gains, arguing that under capitalism, partial victories over obscurantism should not be under-estimated, and insisting that he saw no difference between wage increases, improvements in prison regimes and in civil rights ("the emancipation of women, for example") and the struggle against the repression of homosexuals, "a struggle which must be fought straightaway". ${ }^{100}$

This acceptance of partial reforms, in a spirit similar to that of Amiens' assertion of the CGT's 'double task' (both revolution and improvements in daily conditions), was motivated by his personal experience of suffering and the knowledge he had of others' suffering, particularly in the villages and small towns of 'la France profonde' (traditionalist, provincial France):

I am thinking above all of those who are imprisoned as 'common criminals' for having tried to satisfy their sexuality by an act which was an expression of their true selves. I am also thinking of all those homosexuals who find great difficulty in coming to terms with themselves, in bearing the social reprobation of which they are the object, and who are haunted by the idea of suicide. I have received some deeply distressing letters from such people. The most urgent thing, since we are not going to transform the world tomorrow, is to help such unfortunate people rediscover a taste for life. ${ }^{101}$ 


\section{The gay liberation movement: a critique}

Guérin was personally never attracted to what he called 'effeminate' gay men, and had an "absolute, physical horror" of cross-dressing. ${ }^{102}$ In the 1920s, most of his sexual partners were heterosexuals - or at least they saw themselves as such, and rejected the homosexual label. For these reasons, although the historian of homosexuality in France Frédéric Martel asserts that he was in a sense "the grandfather of the French homosexual movement", Guérin had never actually mixed that much with other declared homosexuals, other than through his association with Arcadie from 1954 and with its review of the same name, to which he contributed from $1956 .{ }^{103}$ Although he was, as he put it, "very well regarded" within Arcadie, he found the organisation complacent, petit-bourgeois and reactionary, not least because its founder, André Baudry, maintained close links with the police and the clergy. ${ }^{104}$ Guérin left in 1968.

When the FHAR (Front homosexuel d'action revolutionnaire) appeared in 1971, Guérin was enthusiastic, seeing the new group as the revolutionary homosexual organisation - bringing together revolutionary politics and a concern with homosexual liberation - he had always longed to see. He was, however, soon disappointed, and found it to be even worse than Arcadie: "Some completely unaware and often very stupid people - except, of course, for a few intelligent young boys such as Guy Maës and Guy Hocquenghem". ${ }^{105}$ Guérin was particularly horrified when, at the funeral of Pierre Overney (a maoist militant killed by security men at Renault-Billancourt), some of the more provocative members of the FHAR exposed their buttocks. ${ }^{106}$

Although it is apparently the case that he stood on a table at the front of the hall and stripped naked with Françoise d'Eaubonne during a general assembly of the FHAR (to reinforce a point being made about the liberation of the body), ${ }^{107}$ Guérin was in other circumstances not a believer in provocation. Explaining once in a talk to fellow Arcadians his intentions in publishing $U n$ jeune homme excentrique, he claimed that he had wanted to present homosexuality in as 'natural' a way as possible, as being part of the life of a 'normal', healthy person, "carefully avoiding the posturing dear to someone such as Jean Genet, for example, that is to say the pose of the 'outcast', the 'damned'. To pose as someone exceptional, in my opinion, is to isolate oneself from common mortals, and gives the heterosexual majority sticks with which to beat us."108 Elsewhere, he commented that although homosexuals must have their own specific organisation, they must also be integrated within a broader movement for change, like black sections within trade unions: "those who content themselves with the ghetto are making a big mistake." 109

By the 1980s, Guérin's assessment of the state of the gay liberation movement and the gay 'scene' was pretty negative. Commercialisation and the 
superficial pursuit of pleasure for pleasure's sake had created, he argued, a generation of young gay men who were frivolous, mindless, obsessed with casual sex and profoundly apolitical - "in a word, a million miles from any conception of class struggle."110 For Guérin, the movement's ghettoisation went against the "breaking down of social barriers" and against the "universal bisexuality", ${ }^{111}$ and that its "public excesses, sometimes even its pointless provocations" 112 had produced "defensive reactions and repulsion" amongst young straight men who might otherwise have been more open sexually. ${ }^{113}$

As has already been commented, despite his repeated assertion that "thanks to the revolution of May 68 , homosexuality finally gained acceptance," 114 and despite the fact that in theory at least the FHAR and the GLH-PQ (Groupe de liberation homosexuelle politique et quotidien) ${ }^{115}$ put the seal on the rapprochement between homosexuality and Revolution, Guérin only found an organisation which fully lived up to his expectations concerning the dialectic of (homo)sexual liberation and social revolution with the creation of the UTCL in 1978. Invited to write a regular column for Gai Pied Hebdo in the early 80 s, Guérin felt obliged to check with the UTCL before agreeing: "Total and unreserved approval" was the Union's response. ${ }^{116}$ The UTCL itself published a pamphlet, Le Droit à la caresse, written by an anonymous gay comrade: 117

There can be no liberation of homosexuality other than on the basis of new social relations, in other words other than in a new society, which is why we are allies with the labour movement in its struggle, the labour movement being the only force capable of bringing about the necessary social change. So, if socialism is not to be a caricature of itself, we, as homosexuals, have a role to play in the class struggle. ${ }^{118}$

In Homosexualité et Révolution, Guérin summarised his strategy, uniting shortterm reforms favouring the civil liberties of homosexuals, women and ethnic minorities with the broader and long-term aims of revolutionary socialism:

The gains won against homophobia by its victims can only be limited and fragile. On the other hand, the crushing of class tyranny would open the way to the total liberation of every human being, including homosexuals. The task therefore is to ensure that there is as great a convergence as possible between homosexuality and revolution. ... The homosexual ... must understand that his liberation can be total and irreversible only if it is achieved within the context of social 
revolution, in other words, only if the human race succeeds not just in liberalizing attitudes, but far more than this, in transforming everyday life. ${ }^{119}$

If, on another occasion, he conceded that the "essential struggle" was that against capitalism and for the liberation of the oppressed proletariat, he nevertheless insisted that this meant not only the struggle for 'economic' liberation, but also the struggle for sexual liberation. "We must not wait for the Revolution, we must not wait for the proletariat to have taken power, and assume that this will automatically bring about sexual liberation." It was exactly the same, Guérin argued, with religion: "No! We must fight obscurantist fanaticism now." 120 All these struggles were 'parallel' struggles within total social revolution.

\section{Conclusion}

Guérin commented once that "the driving force of my life has been love". ${ }^{121}$ Perhaps this provides the unifying principle underlying all of Guérin's work. As he wrote in 1959 in the foreword to an essay about the censorship of homosexual writers:

The problem in reality is not homosexuality. It is, above and beyond that, the problem of sexual liberation, or rather, more generally even than that, it is the problem of freedom. Eroticism is one of the instruments of freedom. There is within it, in the words of Simone de Beauvoir, a principle which is hostile to society, or, more precisely, hostile to a society in which man oppresses man, hostile to the authoritarian society. ${ }^{122}$

There are nevertheless clearly some aspects of Guérin's sexual attitudes or practices which are not unproblematic, notably his tendency to objectify his sexual partners and to idealise working-class youth. As Sedgwick very eloquently put it:

Guérin's desires have always been framed less in terms of a body than of an embodiment: the lovers pass as successorincarnations of an active, questing proletariat, a mass of privacies summating through their plenitude and their sameness into a collective public subject. It is a myth of working-class virility which yokes Guérin's syndicalism with his sexual nature, in an idealisation which echoes the less erotic (but 
equally ethereal) mythology of the proletariat-as-agent heralded by a Sorel or a Lukács. ${ }^{123}$

Guérin also tended (particularly through his masochism, his fetishism and his adherence to somewhat stereotypical, reductionist representations of physical beauty) to reproduce exploitative relations similar to those which have been much targeted by feminism.

To some extent, Guérin was aware of these contradictions - the contradictions, in Sedgwick's words, "between the egalitarian and emancipatory values which the Left canvasses for the reform of society, and the metaphysics of abasement, domination or objectivation which seem to characterise sexual relations of a certain intensity"124 - and in Eux et lui, notably, he submitted himself to a public and painfully honest autocritique.

Sedgwick argues, quite rightly, that Guérin's linking of his homosexual proclivities with the proletariat seen as social vanguard "does not establish the radicalism of Guérin's sexual choice within the terms of sexual politics itself." 125 And he goes on to claim that our modern awareness of sexual politics has tended historically to derive not from the class-struggle-oriented Marxists and anarchists, but "from liberal feminists, or from Utopians like Fourier and Owen who have rejected the class-struggle in industry, or from a women's movement which from the nineteenth century to the present has been seldom entirely happy with the definition of radical priorities offered by even the most revolutionary of males." ${ }^{126}$ Quite apart from the fact that this claim is at least in part questionable, Sedgwick also seems to have been ignorant of Guérin's writings on sexuality other than the autobiographical texts. For, although Guérin adhered to the orthodox Marxist (or Engelsian) argument according to which the patriarchal family, private property and the state were both coterminous and historically determined, it is precisely in the Utopian Fourier, in the individualist anarchists Armand and Stirner, in Reichian psychoanalysis and in the liberal sexologist Kinsey that Guérin found the ideas he needed to produce a critique of labour movement homophobia and to tie this up with a socialist critique of bourgeois patriarchy. Sedgwick concluded his analysis of the contradictions in Guérin by arguing that:

In his more personal, experiential writing, Guérin is unwittingly correcting the entire theoretical orientation of his public socialism: his oscillation between a masculine public sphere of production and a quasi-feminine world of the heart is the penalty of the double life forced on him by society's ban. ${ }^{127}$

This is doubtless true of an earlier period in Guérin's life. But surely what 
characterises Guérin's activism and his non-autobiographical writings from the 1950s onwards, and particularly after his coming out in 1965 , is his move away from Marxism-Leninism and towards anarchism, away from the point of production and towards a breaking down of the artificial barrier between the "public' and the 'private', towards a growing commitment to sexual and especially homosexual liberation, and an attempt both on a theoretical and on a practical, organisational level to bring these two aspects of total social revolution together.

The issue of homosexuality had acquired ever greater importance in Guérin's life, and, in an interview he gave at the age of 75, he made the following remarks about a collection of essays, which he evidently thought might be his last, entitled Son testament:

I have been keen to let it be known that I would like my last publication, my last thoughts, to focus on my love of boys. ... I could have produced a synthesis of my thoughts about revolution, antimilitarism, anticolonialism, etc. If I was insistent that my last book should be called His Testament, it is because I think that homosexuality has played such a primordial role in my life, that it has haunted me day and night from the age of 15 , that that is the message I wish to leave behind. The fact that I am married, a father, a grandfather, bisexual, homosexual, this explosive whole, it seems to me that this is what I must leave behind as the final expression of my life as a writer and as a man. ${ }^{128}$

Finally, to conclude, I can do no better that to quote an assessment of Guérin's contribution in the form of a letter to him from Pierre Hahn, a leading left-winger in the gay lib movement and a founder member of the FHAR:

More than to any other, homosexuals are grateful to you and I more than anyone - for everything you have done for them, and that at a time when to speak out in such a way brought with it great disrepute. ... But your most valuable contribution is a life's work which is at once political (in the traditional sense of the word) and sexological: it is La Peste brune plus Kinsey; it is Fourier and the texts against colonialism; it is, above all, you yourself. ${ }^{129}$ 
This is a revised and much expanded version of a paper first given to the 38th International Conference of Labour and Social History, Linz, September 2002: see Sexualität, Unterschichtenmilieu und Arbeiter Innenbewegung, ed. Paul Pasteur, Sonja Niederacher \& Maria Mesner (Vienna: ITH \& Akademische Verlagsanstalt, 2003). I am grateful to the British Academy for financial assistance which enabled me to carry out research in France in 2002, notably on Daniel Guérin's archives in the Bibliothèque de Documentation Internationale Contemporaine in Nanterre, and also in the Bibliothèque Nationale in Paris. I would also like to thank Gill Allwood and two anonymous readers for their extremely helpful comments on earlier drafts of this paper.

\section{Notes}

${ }^{1}$ Eux et lui, extracted in Homosexualité et Révolution (Saint-Denis: Le Vent du ch'min, 1983), 44. 'Phallism': "A neologism of my own making, meaning the preference for the phallus."

${ }^{2}$ Homosexualité et Révolution, 25.

${ }^{3}$ For brief biographical accounts, see the entries by David Berry in A Biographical Dictionary of French Political Leaders since 1870, ed. David Bell, Douglas Johnson and Peter Morris (London: Harvester Press for the Association for the Study of Modern and Contemporary France, 1990), 191-3; by David Berry in Encyclopedia of Modern French Thought, ed. Christopher John Murray (New York and London: Fitzroy Dearborn, 2004), 280-2; by Didier Eribon in Dictionnaire des cultures gays et lesbiennes, ed. Didier Eribon (Paris: Larousse, 2004), 231-2; by Jean Maitron in Dictionnaire Biographique du Mouvement Ouvrier Français, ed. Jean Maitron (Paris: Edns. ouvirères), vol. XXXI (1988), 33-5; by Michael Sibalis in Who's Who in Contemporary Gay and Lesbian History, From World War II to the Present Day, ed. Robert Aldrich and Garry Wotherspoon (London: Routledge, 2001), 171-2. For a broader discussion of Guérin's life and importance, see my " Un contradicteur permanent': The ideological and political itinerary of Daniel Guérin," in After the Deluge: New Perspectives on Postwar French Intellectual and Cultural History, ed. Julian Bourg (Lanham, MD: Lexington Books, forthcoming). For a bibliography of Guérin (primary and secondary) and for details of a conference on Guérin to be held at Loughborough University, England, 17-19 September 2004, see my web page at: http://wwwstaff.lboro.ac.uk/ eudgb/DG.htm.

${ }^{4}$ In Question de méthode quoted in Ian Birchall, "Sartre's Encounter with Daniel Guérin," Sartre Studies International 2, 1 (1996), 48.

${ }^{5}$ Aimé Césaire, Introduction to Daniel Guérin, Les Antilles décolonisées (Paris: Présence africaine, 1956), 9-17.

${ }^{6}$ See Chomsky's Introduction to Daniel Guérin, Anarchism: From Theory to Practice (New York: Monthly Review Press, 1970), vii-xx.

7 "Une lettre du regretté Pierre Hahn," in Daniel Guérin, Homosexualité et révolution (Paris: Le Vent du ch'min, 1983), 43. See Michael Sibalis, "Pierre Hahn (1936-81)," in Who's Who in Contemporary Gay and Lesbian History, 175-6.

${ }^{8}$ Daniel Guérin, Le feu du sang. Autobiographie politique et charnelle (Paris: Bernard Grasset, 1977), 7. Guérin was convinced that the origins of Proudhon's homophobia and misogyny could be found in a repressed homosexuality. See "Proudhon refoulé 
sexuel," in Proudhon oui et non (Paris: Gallimard, 1978), 195-230. This was a revised and expanded version of "Proudhon, un refoulé sexuel" which had earlier appeared in Essai sur la révolution sexuelle après Reich et Kinsey (Paris: Belfond, 1969) and which was recently republished as a pamphlet by Editions Turbulentes. The text was originally published in two parts: "Proudhon et l'amour «unisexuel»," Arcadie nos.133 \& 134 (janvier \& février 1965). Guérin was apparently much criticised by anarchists (particularly Abel Paz, biographer of Durruti) unhappy at this iconoclasm - "Géographie passionnelle d'une époque. Entretien avec Daniel Guérin," Débattre 10 (printemps 2000), 10. On this aspect of Proudhon, see also Antony Copley, "Pierre-Joseph Proudhon: A Reassessment of his rôle as a Moralist," French History 3, 2 (June 1989). ${ }^{9}$ Jean Maitron, in Dictionnaire Biographique du Mouvement Ouvrier Français, ed. Jean Maitron (Paris: Edns. ouvirères), vol. XXXI (1988), 33-5; Daniel Guerrier, "Daniel Guérin. Un militant sans frontières," Le Monde libertaire no.705 (April 1988).

${ }^{10} \mathrm{Cf}$. the editor's introduction to Recognition Struggles and Social Movements: Contested Identities, Agency and Power, ed. Barbara Hobson (Cambridge University Press, 2003).

${ }^{11}$ Homosexualité et Révolution, 11.

${ }^{12}$ In Daniel Guérin, TV documentary by Jean-José Marchand, questionnaire and interviews by Pierre André Boutang (Archives du XXe Siècle, FR3, 4 \& 11 September 1989; film made in 1985). Interview material was re-used by Laurent Muhleisen and Patrice Spadoni in Daniel Guérin, 1904-1988: Combats dans le siècle (Productions Imagora, n.d.), available from Alternative Libertaire (www.alternativelibertaire.org).

${ }^{13}$ Autobiographie de jeunesse. D'une dissidence sexuelle au socialisme (Paris: Belfond, 1972), 9.

${ }^{14}$ Ibid., 126-7. Charles Maurras (1868-1952) was the leader of the extreme-right Action Française organisation.

${ }^{15}$ See ibid., 161-3.

${ }^{16}$ Autobiographie de jeunesse, 162.

${ }^{17}$ Homosexualité et Révolution, 13.

18 "Interview à la revue Homo 2000, 1979" extracted in ibid., 64.

19 "Daniel Guérin: d'une dissidence sexuelle à la révolution," Interview with Jean-Pierre Joecker \& Alain Sanzio, Masques. Revue des homosexualités 1 (1979?), 42. Extract also in Homosexualité et Révolution, 64.

${ }^{20}$ Autobiographie de jeunesse, 175.

21 Ibid., 167.

22 "Le mouvement ouvrier et l'homosexualité. Entretien avec Daniel Guérin," L'Etincelle 39 (24 November 1977). L'Etincelle was the organ of the Leninist OCT (Organisation communiste des travailleurs, Workers' Communist Organisation). This issue contained a dossier on homosexuality prepared by its "Commission Homosexualité," whose very existence is perhaps noteworthy, although according to the UTCL's booklet, Le Droit à la caresse (about which see below), this Commission existed in name only. A copy of the paper may be found in the Fonds Guérin, BDIC, $\mathrm{F}^{\circ}$ delta 721/15. On the place Guérin went to live in Belleville, see Patrice Spadoni, "Daniel Guérin - 5 rue Lesage," in Claire Auzias et al, Un Paris révolutionnaire. Emeutes, subversions, colères (Paris: L'esprit frappeur, 2001), 366-8. 
${ }^{23}$ Autobiographie de jeunesse, 218.

${ }^{24}$ Ibid., 219. See also comments on his 1929 novel La Vie selon la chair (Paris: Albin Michel), in an "Avant-propos inédit de 1982," Homosexualité et Révolution, 32: "For Hélène, as for me at the time, there was only one reality, the body, arms, legs, lips. They filled my horizons. They stopped me seeing the ugliness of the world, and death. ... At the end of the book, Hélène, who can take no more of her frenetic love life, was looking for a value able to replace the flesh. This value, of which I would make, for my own uses, a counterweight rather than a substitute, I would find in revolutionary commitment - but without completely renouncing sexual relationships with young workers."

25 "Daniel Guérin: d'une dissidence sexuelle à la révolution," 41.

${ }^{26}$ Homosexualité et Révolution, 13.

27 Ibid., 14.

28 "Daniel Guérin «à confesse»," interview with Gérard Ponthieu, Sexpol 1 (20 January 1975), 12-13. Was Guérin exaggerating here? There is evidence to suggest that the few dance halls where men could dance together had a bad reputation as a result. On the rue de Lappe, see Claude Dubois, La Bastoche: Bal-musette, plaisir et crime, 1750-1939 (Paris: Edns. du Félin, 1997), 218-22.

${ }^{29}$ Gilles Barbedette and Michel Carassou, "Entretien avec Daniel Guérin," in Paris Gay 1925 (Paris: Presses de la Renaissance, 1981), 46.

${ }^{30}$ Florence Tamagne, L'Histoire de l'homosexualité en Europe: Berlin, Londres, Paris, 1919-1939 (Paris: Seuil, 2000), 393.

${ }^{31}$ Homosexualité et Révolution, 11. "I felt as if I was cut in two, speaking out loud about my convictions as an activist and, by force of circumstance, feeling obliged to hide my sexual inclinations."

${ }^{32}$ Ibid.

33 "Daniel Guérin: d'une dissidence sexuelle à la révolution," 39-40.

34 "Etre homosexuel et révolutionnaire," La Quinzaine littéraire 215 (August 1975), 9.

"Etre homosexuel et révolutionnaire" was also reproduced in Homosexualité et Révolution, 36-42.

${ }^{35}$ See, for instance, "La répression de 1'homosexualitê en France," La Nef, mars 1958, and "Pour le droit d'aimer un mineur," Marge 4, November-December 1974. "Contrary to myth, homosexuality is not a "rich man's vice'."

36 "Etre homosexuel et révolutionnaire," 10. For anecdotes concerning the difficult situations Guérin sometimes found himself in, see Front populaire, Révolution manquée (Arles: Actes Sud, 1997), 76, and "Etre homosexuel et révolutionnaire," 10 (about his suppressed love for the syndicalist Maurice Chambelland); and Mohammed Harbi, Une vie debout. Mémoires politiques (Paris: La Découverte \& Syros, 2001), Tome I: 1945 $1962,110-12$ (for an example of the ways in which homophobic 'comrades' could cause Guérin political problems).

${ }^{37}$ Homosexualité et Révolution, 12.

${ }^{38}$ Ibid.

${ }^{39}$ A revolutionary socialist with strong syndicalist sympathies in the 1930 s and a Trotskyist in the 1940s, Guérin gradually moved away from bolshevism and closer to anarchism in the 1950s. In the 1960s he went through what he called a 'classical anarchist' phase, before rediscovering Marxism and in particular Rosa Luxemburg in the late 
1960s and early 1970s. During the last twenty years or so of his life, he argued for a revolutionary synthesis of anarchism and Marxism, at the same time as campaigning openly for gay rights. On this ideological itinerary, see the preface to Guérin's $A$ la recherche d'un communisme libertaire (Paris: Spartacus, 1984).

${ }^{40}$ Introduction to Malcolm X and Alex Haley, L'Autobiographie de Malcolm X, trans. Anne Guérin (Paris: Grasset, 1966; 1993).

${ }^{41}$ Un jeune homme excentrique. Essai d'autobiographie (Paris: Julliard, 1965). The 1972 Autobiographie de jeunesse was a later, unexpurgated version of this. It is true that Guérin had come out a few years earlier with the publication of a shorter and more poetic work entitled "Eux et lui" (published in Les Lettres nouvelles no. 26, 21 October 1959, 28-39, and as a book in 1962 by Editions du Rocher, Monaco, with illustrations by André Masson), but the readership was so small it passed unnoticed by most. The fact that it was published outside of France may also have made a difference. Guérin's archives contain congratulatory letters on 'Eux et lui' from, amongst others, Aimé Césaire, Samuel Beckett, François Mauriac, Michel Leiris and André Baudry (Fonds Guérin, BDIC, $\mathrm{F}^{\circ}$ delta 721/8). A recent republication contains both the original 1962 version and a 1979 version of Eux et lui and Commentaires, plus Guérin's marginalia (Lille: GaiKitschCamp, 2000).

${ }^{42}$ Homosexualité et Révolution, 9.

43 "Etre homosexuel et révolutionnaire," 36.

44 "Le mouvement ouvrier et l'homosexualité." Guérin made similar remarks in an interview with the same title published in Gerard Bach, Homosexualités: Expression/Répression (Paris: Le Sycomore, 1982), 99-102. Engels refers to the "degradation" caused by "the perversion of boy-love" - Friedrich Engels, The Origin of the Family, Private Property and the State (New York: Pathfinder Press, 1972), 93.

45 "Sur le racisme anti-homosexuel," Masques. Revue des homosexualités 6 (Autumn 1980), 52.

${ }^{46}$ Homosexualité et Révolution, 17.

47 "Aragon, victime et profiteur du tabou," in Gai Pied Hebdo, 4 June 1983, reproduced in Homosexualité et Révolution, 63. Pierre Albertini's entry on communism in Dictionnaire de l'homophobie, ed. Louis-George Tin (Paris: PUF, 2003), 103-6, suggests that it was the PCF's "natalist and homophobic turn" in 1934 which definitively alienated Guérin from the party. I am not aware of any evidence to support this claim, and it is difficult to understand why, if it were true, Guérin should have failed to mention it in his semi-autobiographical account of the period, Front populaire, which discusses, for instance, the homophobia of Monatte et al.

${ }^{48}$ See "Daniel Guérin «à confesse»", 11. According to Jean-Louis Franc, an activist in the FHAR (Front homosexuel d'action révolutionnaire, discussed below) at the same time as Guérin, the Lambertists were violent towards homosexuals and the Maoists even more so, whereas Lutte ouvrière activists, although the party was programmatically opposed to homosexuality, in practice behaved quite normally towards homosexuals. In conversation with the author, Linz, 14 September 2002. One of the appendices to Girard, Le mouvement homosexuel, provides details of the positions adopted in 1981 by the different political parties.

49 "Etre homosexuel et révolutionnaire," 10.

${ }^{50}$ Kinsey et la sexualité (Paris: Julliard, 1954), 184-5. 
51 "Etre homosexuel et révolutionnaire," 10.

52 Letter of 27 May 1955, Fonds Guérin, BDIC, $F^{\circ}$ delta 721/carton 12/4, quoted in Chaperon, "Le fonds Daniel Guérin et l'histoire de la sexualité," Journal de la BDIC 5 (June 2002), 10.

${ }^{53}$ Foreword to Autobiographie de jeunesse, 9.

54 "Etre homosexuel et révolutionnaire," 10.

${ }^{55}$ See "Daniel Guérin «à confesse»", 10-14.

56 "Etre homosexuel et révolutionnaire," 10.

${ }^{57}$ Ibid. Guérin's, L'Anarchisme, de la doctrine à la pratique (Paris: Gallimard, $1^{\text {st }}$ edition 1965) is widely regarded as one of the best short introductions to anarchism. The English translation (New York: Monthly Review Press, 1970) was given a preface by Noam Chomsky.

58 "Daniel Guérin: d'une dissidence sexuelle à la révolution," 42.

${ }^{59}$ From a letter attached by Guérin to an off-print of a journal article of his held in the Bibliothèque Nationale: “André Gide et l'amour," Arcadie 49 (January 1958): 3-8.

${ }^{60}$ The UTCL was to transform itself into the present-day Alternative Libertaire in 1991. See Georges Fontenis, Changer le monde. Histoire du mouvement communiste libertaire, 1945-1997 (Editions Le Coquelicot/Alternative Libertaire, 2000), 171-5.

${ }^{61}$ Homosexualité et Révolution, 9.

${ }^{62}$ Ibid., 10.

${ }^{63}$ Ibid., 10-11. This is reminiscent of Guérin's repeated expressions (in his autobiographies) of feelings of guilt at his bouts of (homo)sexual self-indulgence. Is this because of his determination in 1930 to 'sublimate' his sexual drive through devotion to the revolution? The assertions of the need to control his sexual drive is reminiscent of Baudry's invocations to Arcadie members.

${ }^{64}$ See Sylvie Chaperon, "Le fonds Daniel Guérin et l'histoire de la sexualité," Journal de la BDIC 5 (June 2002), 10, and "Kinsey en France: les sexualités féminine et masculine en débat," Mouvement social 198 (January-March 2002): 91-110.

${ }^{65}$ The book was dedicated to his father Marcel, "who was one day taken to task (by an over-watchful mother) for reading Havelock Ellis without hiding the fact from his children." Marcel Guérin was also bisexual. On Guérin and the reception of Kinsey in France, see Chaperon, "Kinsey en France," Mouvement social 198 (January-March 2002), 91-110, and "Le fonds Daniel Guérin".

66 "Kinsey et la sexualité, 1955" in Homosexualité et Révolution, 32.

${ }^{67}$ L'en dehors appeared weekly, 1922-39. Armand was, however, quite isolated within the French anarchist movement and his concern with sexual freedom (and in particular his willingness to accept homosexuality) were not, I believe, widespread among French anarchists. See D. Michels, "Anarchisme," in Dictionnaire des cultures gays et lesbiennes, 30-31.

${ }^{68}$ Guérin, Ni Dieu ni Maître, Anthologie de l'anarchisme (Paris: La Découverte, 1999), vol. I, 12. Guérin began his anthology of anarchist texts - first published in 1965 - with the 'precursor' Stirner; he also added an appendix on Stirner to the 1981 edition of his short exposé, L'anarchisme: De la doctrine à la pratique. See also Homosexualité et Révolution, 12; and "Stirner, «Père de l'anarchisme»?," La Rue 26 (1er et 2ème trimestre 1979): 76-89. 
${ }^{69}$ Homosexualité et Révolution, 15.

70 "Le nouveau monde amoureux de Fourier," Arcadie nos. 168 \& 169 (1967 \& 1968), 554.

${ }^{71}$ Ibid., 560. 'Harmonie' was the name given by Fourier to his ideal society.

${ }^{72}$ Charles Fourier, Vers la liberté en amour (Paris: Gallimard, 1975); preface by Guérin, 13-47.

73 “Hommage à Wilhelm Reich," 15-16.

74 "Wilhelm Reich aujourd'hui," in Essai sur la révolution sexuelle, 21. This is the text of an introduction to a debate organised in Brussels by "Liaison 20" on 29 November 1968.

${ }^{75}$ Quoted in Jean Le Bitoux, Les oubliés de la mémoire (Paris: Hachette, 2002), 23.

76 “The most serious difficulty raised in Guérin's combination of radicalism and gayness is hardly touched on in his memoirs. This is the simple issue of whether the celebration of male homosexuality is supportive, or on the contrary obstructive, in that larger question of sexual politics: women's emancipation" - Peter Sedgwick, "Out of hiding: the Comradeships of Daniel Guérin," Salmagundi: A quarterly journal of the humanities and social sciences 58-9 special issue on homosexualism (June 1982), 215.

${ }^{77}$ Reed's publications (all with Pathfinder, New York) include Woman's Evolution from Matriarchal Clan to Patriarchal Family (1992), Problems of Women's Liberation: A Marxist Approach (1972) and an introduction to a 1972 edition of Engels' The Origin of the Family.

${ }^{78}$ Sedgwick, "Out of hiding," 215. See La lutte de classes sous la Première République, 1793-1797 (Paris: Gallimard, 1968), vol.I, 271-8.

${ }^{79}$ “La répression de l'homosexualité en France," 1.

${ }^{80}$ Ibid., 1-2. See also Michael D. Sibalis, "Homophobia, Vichy France, and the "Crime of Homosexuality': The Origins of the Ordinance of 6 August 1942," GLQ 8 (2002), 301-18.

${ }^{81}$ Homosexualité et Révolution, 16.

82 "Kinsey," in ibid., 33. Similar points were developed in "Entretiens avec Daniel Guérin," Homo 2000 no. 4, 3e trimestre 1979. A corrected TS of the text of this interview can be found in Fonds Guérin, BDIC, $\mathrm{F}^{\circ}$ delta 721/15.

83 "Eux et lui," in Son Testament (Paris: Encre, 1979), quoted in Homosexualité et Révolution, 33-34.

84 "Géographie passionnelle d'une époque," 6. See also Homosexualité et Révolution, 16 , note 2. Limitations of space prohibit any detailed discussion here of the idea of androgyny, but it can be argued that androgyny "has often functioned as a conservative, if not misogynistic, ideal" in western civilisations - Kari Weil, Androgyny and the Denial of Difference (Charlottesville: University Press of Virginia, 1992), 2. There may be interesting questions to be asked here about possible connections between such an interpretation and what seems to have been Guérin's male-centred view of the world.

${ }^{85}$ Eux et lui (Lille: GayKitschCamp, 2000), 23-24.

${ }^{86}$ Homosexualité et Révolution, 20: "Many intolerant and aggressive homophobes are nothing more than homosexuals who have painfully repressed their natural tendencies and secretly envy those who have chosen to give their own desire free rein."

${ }^{87}$ Ibid., 23. 
${ }^{88}$ Ibid., 8.

89 "Géographie passionnelle d'une époque," 6.

${ }^{90}$ Homosexualité et Révolution, 16.

91 "Sur le racisme anti-homosexuel," 50.

92 See Robert Aldrich, Homosexuality and Colonialism (London: Routledge, 2003) and "Homosexuality in the French Colonies," in Homosexuality in French History and Culture, ed. Jeffrey Merrick and Michael Sibalis (Binghamton, NY: Harrington Park Press, 2001), 201-18.

93 "Lettre d'un auditeur," in Daniel Guérin, Cuba-Paris (Chez l'auteur: 13 rue des Marronniers, Paris 16e, Mai 1968), 29.

${ }^{94}$ Essai sur la révolution sexuelle après Reich et Kinsey (Paris: Belfond, 1969); Pour un marxisme libertaire (Paris: Laffont, 1969). In later years Guérin would talk of 'libertarian communism' rather than 'libertarian Marxism', in order not to offend his new anarchist friends, but it was only a change of label. He remained faithful to historical materialism and to class analysis all his life.

95 Le Monde, 15 November 1969.

96 See Sylvain Pattieu, Les Camarades des frères. Trotskistes et libertaires dans la guerre d'Algérie (Paris: Syllepse, 2002); preface by Mohamed Harbi.

97 See D. Guérin, Rosa Luxemburg et la spontanéité révolutionnaire (Paris: Flammarion, 1971; republished by Spartacus, 1982) and "Spontanéïté au colloque de Korçula," La Révolution prolétarienne 274 (1971), 6-10.

98 Le Monde, 15 November 1969.

${ }^{99}$ Homosexualité et Révolution, 15-16.

${ }^{100}$ Interview with Pierre Hahn, Plexus, no. 26 (July 1969), 123. Extracts also in Homosexualité et Révolution, 56-59.

101 Plexus, no.26 (July 1969), 123-4.

102 "Daniel Guérin «à confesse»," 14.

${ }^{103}$ Frédéric Martel, Le rose et le noir. Les homosexuels en France depuis 1968 (Paris: Seuil, 2000), 46. The monthly review Arcadie was founded by André Baudry in 1954 and the association (the Club littéraire et scientifique des pays latins) in 1957. Arcadie had about 10000 members at the end of the 1960s. See Martel, 98-117; Jacques Girard, Le mouvement homosexuel en France, 1945-1980 (Paris: Syros, 1981), ch. 3; Olivier Jablonski, "André Baudry," in Who s Who in Contemporary Gay and Lesbian History, 32-34.

104 "Le mouvement ouvrier et l'homosexualité."

105 Elsewhere, however, Guérin was less complimentary about Hocquenghem. Asked by L'Etincelle in 1977 what he thought of other "écrivains de l'homosexualité", "homosexual writers", he replied: "Hocquenghem writes in an incomprehensible gobbledygook, Bory overdoes it, he's the clown of homosexuality, and what's more he's turning into a reactionary, he went to dinner with Giscard; as for Peyrefitte, he is despicable and odious." On Hocquenghem, Bory and Peyrefitte, see Marcel, Le Rose et le Noir and Girard, Le mouvement homosexuel. On Hocquenghem, see also Bill Marshall, Guy Hocquenghem. Theorising the Gay Nation (London: Pluto, 1996). Maës was the editor of the FHAR's paper, L'Antinorm.

106 On the Overney incident, see Martel, Le rose et le noir, 52. Along with a few copies 
of L'Antinorm, Guérin's archives also contain a 2pp. TS document, "Pour la constitution et l'organisation d'une tendance «politique» au sein du FHAR" ("For the constitution and organisation of a 'political' tendency within the FHAR"), but I have found no further evidence of Guérin's having been involved in any attempt to reform the FHAR. He seems to have had closer links with David Thorstad, leader of the Gay Activist Movement, the left-wing tendency within the American gay lib movement. Fonds Guérin, BDIC, $\mathrm{F}^{\circ}$ delta $721 / 15$.

${ }^{107}$ See Martel, Le rose et le noir, 45-6.

108 "Commentaires très libres sur les Mémoires d'un jeune homme excentrique," 17 February 1965 (unpublished bound TS held in Bibliothèque Nationale).

109 "Le mouvement ouvrier et l'homosexualité."

${ }^{110}$ Homosexualité et Révolution, 17.

111 Ibid., 23.

112 Ibid.

113 Paris Gay 1925, 54.

${ }^{114}$ Homosexualité et Révolution, 23.

115 See Jean Le Bitoux, "The Construction of a Political and Media Presence: The Homosexual Liberation Groups in France between 1975 and 1978," in Homosexuality in French History and Culture, ed. Jeffrey Merrick and Michael Sibalis (Binghamton, NY: Harrington Park Press, 2001), 249-64.

116 "Libertaires et gais," Gai Pied Hebdo 52 (15-21 January 1983), 15.

117 Union des Travailleurs Communistes Libertaires, Le Droit à la caresse: Les homosexualités et le combat homosexuel (Paris: Editions «L», n.d.; Supplement to Tout le Pouvoir aux Travailleurs no.27 and to Lutter), 32. I am grateful to comrades of the Centre International de Recherches sur l'Anarchisme in Marseille for unearthing a copy of this for me. The title of the pamphlet is evidently a pun on Paul Lafargue's The Right to be Lazy, which translates into French as Le Droit à la paresse. It includes a useful summary of the history of the homosexual liberation movement and its connections with the left and the trade union movement

${ }^{118}$ Le Droit à la caresse, also quoted in "Libertaires et gais."

119 Homosexualité et Révolution, 25.

120 "De la répression sexuelle à la Révolution," from le Point, Brussels, December 1968, in ibid., 34.

121 "Géographie passionnelle," 6.

122 Shakespeare et Gide en correctionnelle? Essais (Paris: Editions du Scorpion, 1959), 9.

${ }^{123}$ Peter Sedgwick, “Out Of Hiding: The Comradeships of Daniel Guérin,” Salmagundi, 58 , part 9 (1982), 210.

124 Ibid., 211.

125 Ibid., 210.

126 Ibid., 210-11.

${ }^{127}$ Ibid., 217.

128 "Interview à la revue Homo 2000, 1979" extracted in Homosexualité et Révolution, 65. Son testament (Paris: Encre, 1979) is divided into two parts, the first bringing together a selection of autobiographical texts, the second a set of texts by or about 'pre- 
cursors': Plutarch, Shakespeare, Fourier, Balzac's Vautrin, Sacher-Masoch and Gauguin.

129 "Une lettre du regretté Pierre Hahn," in Homosexualité et Révolution, 43. La Peste brune (Paris: Librairie du Travail, 1933), written after Guérin's return from a tour of Germany, has been translated by Robert Schwartzwald: The Brown Plague: Travels in Late Weimar and Early Nazi Germany (Durham \& London: Duke University Press, 1994). 